https://www.amerabra.org; https://fspu.uitm.edu.my/cebs; https://www.emasemasresources.com/ $5^{\text {th }}$ ABRA International Conference on Quality of Life Holiday Villa Langkawi, Langkawi Island, Malaysia, 15-16 Dec 2021

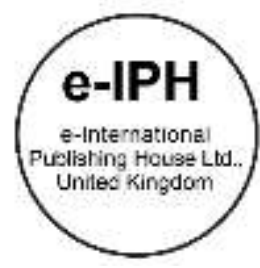

\title{
Qualitative Assessment of Entrepreneurial Activities of Malaysian Private Tahfiz Institutions (PTls)
}

\author{
Norazmi Anas ${ }^{1}$, Muhammad Hafiz Saleh², Zuriani Yaacob ${ }^{3}$, \\ Mohd Aariffin Mohd Taharin ${ }^{4}$, Wahibur Rokman ${ }^{5}$
}

${ }^{1}$ Academy of Contemporary Islamic Studies (ACIS), Universiti Teknologi MARA, Perak Branch, Tapah Campus, Perak, Malaysia

${ }^{2}$ Faculty of Quranic dan Sunnah Studies (FPQS), Universiti Sains Islam Malaysia, Negeri Sembilan, Malaysia

${ }^{3}$ Akademi Pengajian Bahasa (APB), Universiti Teknologi MARA, Pahang Branch, Raub Campus, Pahang, Malaysia

${ }^{4}$ Academy of Contemporary Islamic Studies (ACIS), Universiti Teknologi MARA, Shah Alam, Selangor, Malaysia

${ }^{5}$ Department of Islamic Economics, State Islamic College, (STAIN), Kudus, Indonesia

norazmianas@uitm.edu.my,mhafiz@usim.edu.my,zurianibtyaacob@uitm.edu.my, haniipin5@gmail.com,Wahibur@gmail.com

Tel: +60122754160

\begin{abstract}
PTIs are encouraged to participate in entrepreneurial activities appropriate for their area and ability. Thus, this qualitative case study where a semi-structured interview with the selected Malaysian Private Tahfiz Institutions (PTIs) was conducted to identify entrepreneurial activities to pay operational and management costs, to analyze the obstacles, limitations, problems faced, and to assess the balance of entrepreneurial activities in educational governance of these religious, educational institutions. The findings demonstrated that involving PTIs in entrepreneurship can cover 40 to 50 percent of total operating costs.
\end{abstract}

Keywords: Qualitative Assessment; Entrepreneurial Activities; Malaysian Private Tahfiz Institutions (PTIs); Malaysia

eISSN: 2398-4287@ 2021. The Authors. Published for AMER ABRA cE-Bs by e-International Publishing House, Ltd., UK. This is an open access article under the CC BYNCND license (http://creativecommons.org/licenses/by-nc-nd/4.0/). Peer-review under responsibility of AMER (Association of Malaysian Environment-Behaviour Researchers), ABRA (Association of Behavioural Researchers on Asians/Africans/Arabians) and CE-Bs (Centre for Environment-Behaviour Studies), Faculty of Architecture, Planning \& Surveying, Universiti Teknologi MARA, Malaysia.

DOI: https://doi.org/10.21834/ebpj.v6i18.3056

\subsection{Introduction}

The establishment of Private Tahfiz Institutions (PTIs) has received an encouraging response to meet the country's mainstream education to produce a generation of high-quality huffaz and contribute to the country's development. However, PTI infrastructure and management standards were discovered to be non-uniform due to the varying backgrounds of each institution's establishment as well as poor governance (Ridza et al., 2017), and a lack of planned and organized work, which affects most aspects of its implementation (Nawi et al., 2014; Nawi \& Salleh, 2017). Government funds, alms, and endowments channeled directly to PTls in Malaysian states such as Selangor, Pahang, Melaka, and several others were insufficient (Azha et al., 2013; Kamal \& Seman, 2017). This is in addition to PTI accountability issues involving illegal fundraising and misgovernance (Fatah, 2014; Bani et al., 2017). Ismail (2016) strongly supports it, stating that the main problems of PTIs are poor educational management and financial resource constraints which have a direct impact on the production of excellent huffaz. The reliance on funding, financial resource constraints, and poor governance have made the viability of PTIs increasingly uncertain, complicating the implementation of the National Tahfiz Education Policy (NTEP), which aims to produce 125,000

eISSN: 2398-4287@ 2021. The Authors. Published for AMER ABRA cE-Bs by e-International Publishing House, Ltd., UK. This is an open access article under the CC BYNCND license (http://creativecommons.org/licenses/by-nc-nd/4.0/). Peer-review under responsibility of AMER (Association of Malaysian Environment-Behaviour Researchers), ABRA (Association of Behavioural Researchers on Asians/Africans/Arabians) and CE-Bs (Centre for Environment-Behaviour Studies), Faculty of Architecture, Planning \& Surveying, Universiti Teknologi MARA, Malaysia.

DOI: https://doi.org/10.21834/ebpj.v6i18.3056 
professional huffaz by 2050. Previous research only focused on recognition, Teaching and Learning (T\&L), and challenges to build quality huffaz - making the main issue of financial restraint to conserve Malaysian PTI's not intensely researched. As a result, PTIs are encouraged to engage in entrepreneurial activities as an alternative to generating their income (Anas et al., 2019) rather than relying solely on government assistance, endowment funds, and public fundraising through charity to elevate and increase a PTI's level of self-sufficiency from time to time. The study aims to identify entrepreneurial activities undertaken by Private Tahfiz Institutions (PTIs) in Malaysia to cover operating and management costs, followed by an analysis of the challenges, constraints, and problems encountered, and an assessment of the balance of entrepreneurial activities in educational governance of these religious, educational institutions.

\subsection{Literature Review}

\subsection{Islamic Entrepreneurship: Fundamentals of Shariah Compliance}

Entrepreneurship is defined as the creation of new things from existing values over some time, a while, and financial resources to make a profit and gain self-satisfaction (Mardia et al.,2021). Furthermore, it seizes the opportunity to combine new resources that influence the market operated by entrepreneurs (Abdullah \& Azam, 2020). From ancient times to the present, entrepreneurship has been a vital part of human life, providing a source of livelihood and income. Therefore, Islamic teachings regard this field as high and noble even if done on a small scale as long as the results are halal in the eyes of Islamic law (Ariyadi, 2018). It is conclusive from Islamic history that the Prophet Muhammad (PBUH) became a role model and icon of Islamic entrepreneurship, followed by some of his companions who were also very successful in the field of entrepreneurship, such as 'Abdurrahman bin' Awf, Az-Zubayr bin al 'Awwam,' Uthman bin 'Affan, Thalhah bin' Ubaydillah and Sa'd bin Abi Waqqash.

Islamic entrepreneurship refers to business activities directly related to religion, making al-Quran and al-Sunnah the primary driving forces behind Islamic entrepreneurial activity (Ramadani, 2021). According to Ashraf (2019), Islamic law significantly influences Islamic entrepreneurial activities to maintain a stable, fair, and balanced Muslim economy. It is also known as shariah-compliant entrepreneurship, guided by two primary levels, namely entrepreneurial behaviors and enterprise actions and strategies (Mebroui \& Mosbah, 2020). The Islamic moral code, which emphasizes wrong and right values, governs the conduct of Muslim entrepreneurs. They are encouraged to exhibit features such as honesty, trust, justice, keeping promises, making timely payments, assisting low-income families and neighbors, and so on. It corresponds to the characteristics of the Prophet Muhammad (PBUH), i.e., Siddiq (Say true or honest), Amanah (Trustworthy), Tabligh (The ability to convey, practical communication ability), and Fathonah (Business intelligence), as mentioned by Syahrul and Abdullah (2019). Being a devout Muslim entrepreneur demonstrates obedience to Allah SWT (Harizan \& Mustafa, 2020). The level of business actions and strategies comes next. Staff relations in a company, type of operation (halal investment), financing conditions, supplier-buyer transactions, corporate social responsibility, and zakat payment are all governed by Shariah.

Hence, it is concluded that Islamic entrepreneurship makes shariah compliance the core of Islamic ethics that Muslim entrepreneurs must follow, so that entrepreneurial activity are carried out in tandem with the preservation of maqasid syariah to gain Allah SWT's pleasure.

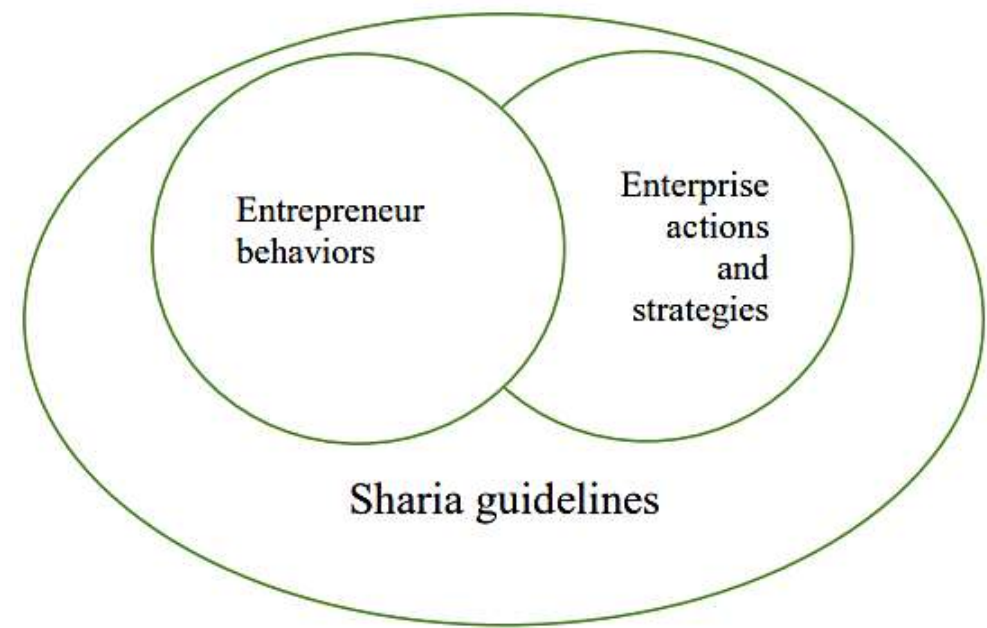

Fig. 1: The Islamic Entrepreneurship Concept

(Source: Mebroui \& Mosbah, 2020)

\subsection{Educational Governance in Malaysian Private Tahfiz Institutions (PTIs)}

In Malaysian Private Tahfiz Institutions (PTIs), educational governance is generally closed. As a result, it is the responsibility of tahfiz education providers (TEPs) to administer their PTIs with the best management, accountability, and integrity to gain parents' trust and maintain its good name (Bani et al., 2017). According to Othman and Anas (2020), PTls are rapidly expanding in Malaysia due to the Muslim community's growing awareness of the importance of understanding the Quran. However, the high demand for Quranic education 
has resulted in the establishment of uncontrolled PTIs, which harm curriculum, financial management, facility governance, academic collaboration with government-recognized institutions, and other areas.

According to Ismail (2016), these institutions face several challenges to survive, including modernization, technology, and certification. Therefore, he proposed several initiatives to strengthen and empower tahfiz institutions, including (i) registering all tahfiz institutions, (ii) curriculum coordination, (iii) establishing a Tahfiz Certificate standard, and (iv) introducing skill-based programs. Entrepreneurship, management, tourism, commercial agriculture, and other fields can also be introduced and offered. The Tahfiz Schools Special Task Force's High-Level Committee has recommended changes to the Education Act 1996 (Act 550) to allow private tahfiz educational institutions to be registered under the act. Its role is to coordinate welfare and assistance. It is also to monitor the governance of tahfiz schools to ensure that they meet the government's standards. Aside from that, six recommendations have been submitted, i.e. (i) Amendment of the Education Act 1996 (Act 550) to include the registration of private religious schools, (ii) Establishment of a framework for approval criteria for the formation and management of maahad tahfiz, (iii) Compliance with minimum safety and health standards, (iv) Establishment of volunteer firefighters, (v) Registration of maahad tahfiz coordinated between state and federal governments and (vi) Joint control and responsibility.

Hence, Islamic education-related bodies in Malaysia, such as the Department of Islamic Development Malaysia (JAKIM), must collaborate with TEP to improve PTI governance by channeling appropriate and adequate assistance, coordinating the tahfiz curriculum in an integrated manner formulating existing tahfiz education standards to meet high demand. Not only that, focusing on producing highquality huffaz remains the main plan to meet the National Tahfiz Education Policy (NTEP) goal of creating 125,000 huffaz by 2050.

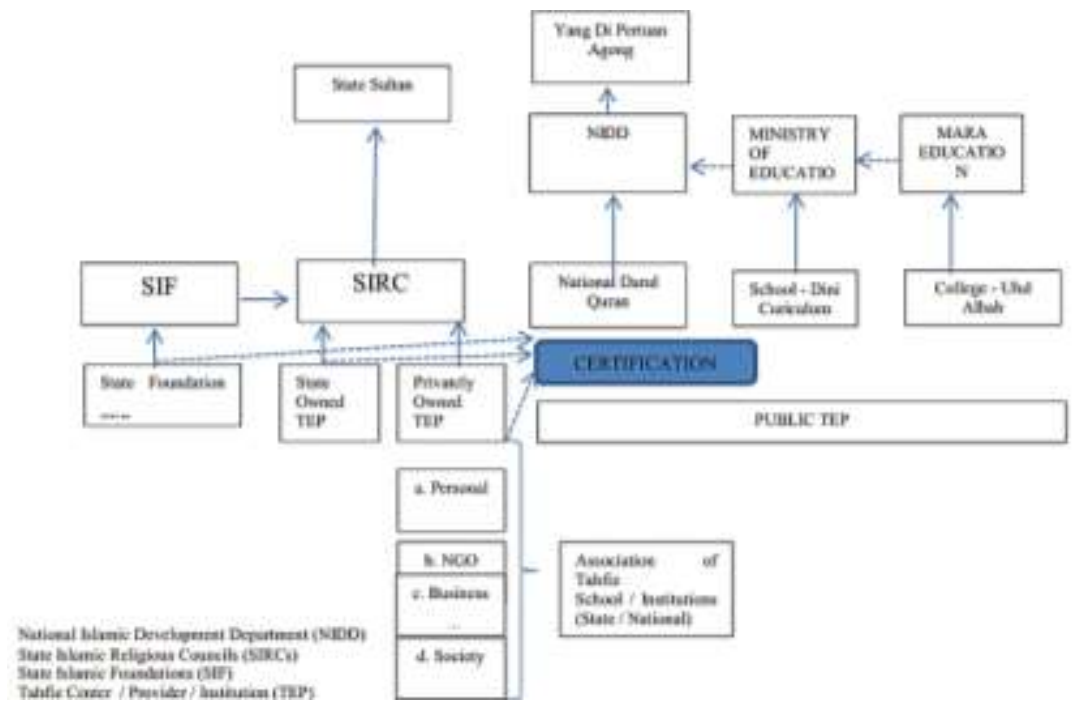

Fig. 2: Governance Framework of Tahfiz Schools in Malaysia (Source: Bani et al., 2017)

Based on the previous literature reviews ranging in the latest five years (2016 to 2021), it was found that research relevant to PTIswere mainly focused on the administration of tahfiz education alone -- like certification, standard and recognition, teaching and learning (TnL), quality huffaz, and the challenges faced by Malaysian PTIs. Even though the financial restraint of PTI's was brought forward in some of the previous research, the solution to such problem was not intensely researched, especially in making entrepreneurship being an exit to such situation. Hence, entrepreneurship is highly encouraged in Islam, to generate halal income that is parallel with Islamic syarak, by making Prophet Muhammad SAW and his companions the role models for successful entrepreneurs.

\subsection{Methodology}

This was a qualitative case study, with the leading research instrument being a semi-structured interview with the founders, principals, and administrators of Malaysian Private Tahfiz Institutions (PTI's) that engage in entrepreneurial activities. Hybrid semi-structured interview sessions were conducted (either through confrontation or online method), based on the participants' preference and safety measures set by the local authority, adhering to the government's Standard Operating Procedure (SOP) due to the COVID-19 pandemic crisis that hit Malaysia throughout the year 2020-2021. The sampling technique used in this study included seven participants (Darusalam \& Hussin, 2016) from Malaysia's selected PTIs. They had two types of entrepreneurial activities, i.e., products and services. Thematic analysis was 
used to analyze the data, which had three main themes: (i) PTI entrepreneurial activities, (ii) Challenges, constraints, and problems faced by PTI's, and (iii) The balance of entrepreneurial activities in educational governance in PTI's.

Table 1. PTI Coding of the Study

\begin{tabular}{lc}
\hline \multicolumn{1}{c}{ Private Tahfiz Institutions } & Codes \\
\hline Institut Tahfiz Al-Quran Lil Muttaqin, Hulu Langat, Selangor & P1 \\
Maahad Tahfiz QIAM, Pantai Remis, Perak & P2 \\
Akademi Tahfiz Al Hira, Rawang, Selangor & P3 \\
Maahad Bahasa dan IImu Al-Quran, Kuantan, Pahang & P4 \\
Maahad Tahfiz Al-Furqan, Temerloh, Pahang & P5 \\
Maahad Tahfiz Wal Qiraat (MTQ), Shah Alam, Selangor & P6 \\
Maahad Tahfiz Sulaimaniyyah, Kajang, Selangor & P7 \\
\hline
\end{tabular}

(Source: Study sampling)

\subsection{Findings}

This section presents the results from the semi-structured interview.

\subsection{PTI's Entrepreneurial Activities}

Based on the findings, six PTI's rely entirely on income generated from entrepreneurial activities to cover their respective institutions' operating costs (P1-P6), while P7 only generates entrepreneurial income as a side income. This is because P7 is a branch of a well-known PTI with 10,000 units around the worldwide. In contrast, P1-P6 is a PTI managed by a local founder. Furthermore, PTI-led entrepreneurial activities were found to be capable of covering between 40 and 50 percent of an institution's operating costs, in addition to tuition fees charged to students, government assistance, alms, and endowments.

"The students only paid $40 \%$ from the maahad's operation cost, forcing us to find the remaining $60 \%$ to accommodate our full operation cost" (P1)

" $40 \%$ to $50 \%$ of the maahad's operation cost is accommodated by our business" (P4)

"The business profit that is shared to our maahad was less than $50 \%$, because $10 \%-20 \%$ of the profit is given to the financier" (P5)

"The maahad's operation cost is estimated to be at RM30,000 per month, whereas the business profit is at RM15,000 per month. Therefore, the maahad's business accommodates half of the operation cost" (P6)

\subsection{Challenges, Constraints, and Problems Faced by PTI's}

The institutions involved in the study face three significant challenges: (i) working capital, (ii) raw material supply and product quality, and (iii) effective marketing of products and services. Other issues include the lack of knowledge in entrepreneurial activities, competition with non-Muslim supermarkets and shops, staff constraints, and negative public perceptions of student involvement in PTI enrolment.

\subsection{The Balance of Entrepreneurial Activities in Educational Governance in PTI's}

All PTI's were balanced in carrying out entrepreneurial activities with separate governance between entrepreneurship and education. This is followed by student involvement that does not interfere with teaching and learning activities and makes entrepreneurial activities a cocurricular training ground for the students.

Table 2. Entrepreneurial Activities of Malaysia's selected PTI

\begin{tabular}{|c|c|c|c|c|c|c|c|}
\hline $\mathrm{T} / \mathrm{P}$ & $\mathrm{P} 1$ & P2 & P3 & $\mathrm{P} 4$ & P5 & P6 & $\mathrm{P} 7$ \\
\hline T1 & $\begin{array}{l}\text { - Cattle, goat \& } \\
\text { duck farming } \\
\text { - Salted eggs } \\
\text { - Herbal } \\
\text { products } \\
\text { - Able to cover } \\
\text { PTI operating } \\
\text { costs }\end{array}$ & $\begin{array}{l}\text { - Restaurant } \\
\text { - Frozen \& smoked } \\
\text { food products } \\
\text { - Aquaculture } \\
\text { - Agriculture } \\
\text { - Able to cover PTI } \\
\text { operating costs }\end{array}$ & $\begin{array}{l}\text { - Wholesaler of } \\
\text { necessities } \\
\text { - Cooperatives \& } \\
\text { convenience } \\
\text { stores } \\
\text { - Able to cover } \\
\text { PTI operating } \\
\text { costs }\end{array}$ & $\begin{array}{l}\text { - Cattle, goat \& } \\
\text { chicken farming } \\
\text { - Agriculture } \\
\text { - Able to cover PTI } \\
\text { operating costs }\end{array}$ & $\begin{array}{l}\text { - Vocational } \\
\text { training } \\
\text { - Restaurant } \\
\text { - Cattle farming- } \\
\text { Aquaculture } \\
\text { - Will } \\
\text { management \& } \\
\text { takaful services } \\
\text { - Amil zakat \& } \\
\text { bank agent } \\
\text { - Able to cover } \\
\text { PTI operating } \\
\text { costs }\end{array}$ & $\begin{array}{l}\text { - Cattle, goat \& } \\
\text { chicken farming } \\
\text { - Fresh \& frozen } \\
\text { meat } \\
\text { - Food-based } \\
\text { products } \\
\text { - Able to cover } \\
\text { PTI operating } \\
\text { costs }\end{array}$ & $\begin{array}{l}\text { - Hajj \& Umrah } \\
\text { travel agents } \\
\text { - Takaful \& } \\
\text { insurance } \\
\text { services } \\
\text { - Halal chicken } \\
\text { processing } \\
\text { - Side income to } \\
\text { PTI }\end{array}$ \\
\hline T2 & $\begin{array}{l}\text { - Livestock } \\
\text { diseases } \\
\text { - Weak product } \\
\text { marketing }\end{array}$ & $\begin{array}{l}\text { - Food quality } \\
\text { - Weak product } \\
\text { marketing } \\
\text { - Lack of } \\
\text { aquaculture \& } \\
\text { agricultural } \\
\text { expertise }\end{array}$ & $\begin{array}{l}\text { - The difference } \\
\text { in the price of } \\
\text { goods between } \\
\text { PTI and non- } \\
\text { Muslim } \\
\text { supermarkets/ } \\
\text { shops }\end{array}$ & $\begin{array}{l}\text { - Negative society's } \\
\text { perception of the } \\
\text { use of student } \\
\text { labour in } \\
\text { entrepreneurial } \\
\text { activities } \\
\text { - Difficulty finding } \\
\text { permanent } \\
\text { employees who } \\
\text { engage in } \\
\text { entrepreneurial } \\
\text { activities }\end{array}$ & $\begin{array}{l}\text { - Limited capital } \\
\text { - Agricultural } \\
\text { products are only } \\
\text { marketed in the } \\
\text { local locality only } \\
\text { \& limited }\end{array}$ & $\begin{array}{l}\text { - Limited capital } \\
\text { - Insufficient } \\
\text { stock of goods } \\
\text { - Limited product } \\
\text { marketing } \\
\text { - Product quality } \\
\text { suitable for the } \\
\text { market } \\
\text { - Staff constraints }\end{array}$ & $\begin{array}{l}\text { - Products \& } \\
\text { services are not } \\
\text { well known } \\
\text { - Lack of } \\
\text { promotion }\end{array}$ \\
\hline
\end{tabular}




\begin{tabular}{|c|c|c|c|c|c|c|c|}
\hline & & & & $\begin{array}{l}\text { - Limited human } \\
\text { resources } \\
\text { - Supply of products } \\
\text { only around the } \\
\text { local locality }\end{array}$ & & & \\
\hline T3 & $\begin{array}{l}\text { - Student } \\
\text { involvement in } \\
\text { entrepreneurial } \\
\text { activities as an } \\
\text { exercise that } \\
\text { does not } \\
\text { interfere with } \\
\text { TnL activities } \\
\text { - Education } \\
\text { according to } \\
\text { the ability of } \\
\text { students } \\
\text { - Balance } \\
\text { between } \\
\text { educational \& } \\
\text { entrepreneurial } \\
\text { activities }\end{array}$ & $\begin{array}{l}\text { - Student } \\
\text { involvement in } \\
\text { entrepreneurial } \\
\text { activities as a co- } \\
\text { curricular exercise } \\
\text { that does not } \\
\text { interfere with TnL } \\
\text { activities } \\
\text { - Not manipulating } \\
\text { students as } \\
\text { employees in } \\
\text { entrepreneurial } \\
\text { activities undertaken } \\
\text { - Balance through } \\
\text { governance is } \\
\text { broken down into } \\
\text { two, i.e. education \& } \\
\text { entrepreneurship }\end{array}$ & $\begin{array}{l}\text { - The involvement } \\
\text { of PTI in } \\
\text { entrepreneurship } \\
\text { depends on the } \\
\text { resources and } \\
\text { expertise of PTI } \\
\text { itself } \\
\text { - No student } \\
\text { involvement in } \\
\text { entrepreneurship } \\
\text { - Balance through } \\
\text { governance is } \\
\text { broken down into } \\
\text { two, i.e. education } \\
\text { \& } \\
\text { entrepreneurship }\end{array}$ & $\begin{array}{l}\text { - Entrepreneurship } \\
\text { and education } \\
\text { schedules are } \\
\text { neatly arranged } \\
\text { - Balance through } \\
\text { governance is } \\
\text { broken down into } \\
\text { two, i.e. education \& } \\
\text { entrepreneurship }\end{array}$ & $\begin{array}{l}\text { - Utilization of } \\
\text { existing PTI } \\
\text { resources in the } \\
\text { involvement of } \\
\text { entrepreneurial } \\
\text { activities }\end{array}$ & $\begin{array}{l}\text { - Entrepreneurial } \\
\text { entities are } \\
\text { segregated with } \\
\text { PTI education } \\
\text { - Fully supported } \\
\text { by parents and } \\
\text { the local } \\
\text { community } \\
\text { - No student } \\
\text { involvement in } \\
\text { PTI } \\
\text { entrepreneurial } \\
\text { activities }\end{array}$ & $\begin{array}{l}\text { - Entrepreneurial } \\
\text { entities are } \\
\text { segregated with } \\
\text { PTI education } \\
\text { - Student } \\
\text { involvement in } \\
\text { the promotion of } \\
\text { PTI products \& } \\
\text { services to } \\
\text { family members }\end{array}$ \\
\hline
\end{tabular}

\subsection{Discussion}

Livestock and agriculture involving cattle, goats, chickens, ducks, and aquaculture such as freshwater fish and banana and vegetable crops are the most popular entrepreneurial activities explored by Private Tahfiz Institutions (PTIs). There are also food-based products such as salted eggs, frozen and smoked foods, herbal products, and so forth, whether fresh or frozen. It is due to the high demand for halal products and nutrition, which are at the heart of Islamic teachings, particularly in Islamic consumer figh (Kamaruddin \& Wahid, 2020). Aside from that, the institutions also engage in service-based entrepreneurship such as will management, takaful, and insurance, Amil Zakat, selected bank agents, and hajj and umrah packages. In comparison to the product-based entrepreneurship category, this servicebased entrepreneurship category does not necessitate a large amount of capital. As a result, PTls that lack capital or significant funding sources can still enter the field of entrepreneurship with little or no money. Based on the findings of the study, it was discovered that the entrepreneurial activities carried out by the institutions can cover the operating costs of each institution up to $50 \%$, which is very significant, especially in the current COVID-19 pandemic era.

Nonetheless, the institutions involved in the study face significant challenges in their respective businesses, such as working capital, goods and services, and effective marketing. According to Sahut and Braune (2021), a company that conducts entrepreneurship will inevitably face financial problems due to limited financial resources at establishing a business entity. Furthermore, the issue of the quality of products for sale is entirely dependent on the supply of raw materials, which is the basis of a business's success in the market. According to Litvaj and Poniiaková (2014), the essential prerequisite for being observed as an entrepreneurial phenomenon is product quality is followed by effective marketing for the stability of products and services in consumer-preferred markets (Bakar \& anak Jimel, 2020). According to Amelia et al. (2019), marketing strategy should focus on seven dimensions, i.e., product, price, place, promotion, people, process, and physical evidence, also known as 7P (Products, Prices, Places, Promotions, People, Processes, and Physical Evidence) as one factor that influences consumer purchasing decisions. Particular attention is also paid to the creation and development of internal brands to face competitive pressures and create a strategic and competitive market position (Zéman \& Bogdan, 2019) and to follow everyday marketing trends that have made digital marketing (E-commerce) the primary product marketing platform and services preferred by current consumers (Noor et al., 2021).

Next, as noted by Fatah (2014) and Bani et al. (2017), the accountability issues plaguing PTIs in Malaysia have given these institutions a lousy image and tarnished their good name. According to the situation, a few PTIs in Malaysia was manipulating and using their students to raise funds to cover the operating costs of their respective premises by asking for alms at petrol stations, banks, and other places where the local community congregated. This situation has demonstrated that the imbalance between this al-Quran education and the responsibility of finding funds should be fully accountable to the management of PTIs. Nonetheless, the findings of this study revealed that there is a balance between education and entrepreneurship in these institutions, with student involvement in entrepreneurship as a cocurricular activity that does not interfere with teaching and learning activities, and the two entities are separated by different management. As can be seen, these PTIs involving education and entrepreneurship are well managed and organized.

The management of al-Quran education that is balanced with entrepreneurship that is practiced by the PTI's perfectly fits the maqasid Syariah's principle, to preserve religion and wealth, and to produce a sustainable and competitive society. It is also parallel with the primary objective of establishing Quran-based religious education, to make quality huffaz who are at par with the other mainstream education available in our country. Moreover, the Islamic entrepreneurship principle that is embedded in the ITS' activities will ensure a halal source of income, prepare Syariah-compliant products and services, and safely guarantee our life, mind, and posterity - which ultimately supports "Buy Muslim First (BMF)" that enhance the Muslims' economy. 


\subsection{Conclusion \& Recommendations}

In addition to tuition fees paid by students, government or private funds, endowments, and alms, entrepreneurial activities carried out by Private Tahfiz Institutions (PTIs) in Malaysia can cover $40 \%$ to $50 \%$ of each institution's operating costs. Nonetheless, they face some challenges such as working capital, product and service quality and effective product marketing to remain stable and competitive. Therefore, the solution that can be proposed to solve this main problem is government intervention through the Ministry of Entrepreneur and Cooperative Development (MEDAC), Malaysian Small and Medium Enterprises Corporation (SME Corp. Malaysia), and the National Entrepreneurship Institute (INSKEN) as well as the involvement of Islamic institutions related to tahfiz such as The Malaysian Islamic Development Department (JAKIM), the State Islamic Religious Council (MAIN), the State Islamic Religious Department (JAIN) and tahfiz associations in our country to provide ample space and opportunities for PTIs to venture into this field of entrepreneurship for their survival in the future. It also indirectly saves government funds by providing annual assistance to PTIs in Malaysia that generate income through entrepreneurial activities and compete in global and international markets. Concerning accountability for the illegal collection of public funds by a small number of PTI operators, the authorities must strictly enforce the law to prevent this activity from becoming widespread. Nonetheless, due to the separation of the two entities into excellent and orderly separate governance, the institutions in the study were found to be balanced in carrying out educational and entrepreneurial activities. Thus, the entrepreneurial activities carried out can be used as an entrepreneurship model that all PTIs in Malaysia can emulate to meet the National Tahfiz Education Policy (NTEP) goal of producing 125,000 huffaz by 2050 .

\section{Acknowledgements}

The study was funded by the Ministry of Education (MOE) under FRGS grant research funds with reference code FRGS/1/2018/SSI03/UiTM/03/1 entitled 'Model Tahfizpreneur Tadbir Urus Tahfiz Swasta di Malaysia'

\section{Paper Contribution to Related Field of Study}

Educational / Learning Environment

\section{References}

Abdullah, M. A., \& Azam, M. S. E. (2020). Halal entrepreneurship from Maqasid-al-Sharia'h perspective: inseparable concept for Halalpreneurs. Food Research, 4(1), 3442.

Amelia, S., Salamah, H., \& Sofyan, M. (2019). Effect of Marketing Strategy and Service Quality Against the Decisions of Parents. Ilomata International Journal of Management, 1(1), 31-37.

Anas, N., Samori, Z., Hamid, M. Y., Zulkipli, S. N., \& Noor, M. S. M. (2019). Private Tahfiz institution governance: A proposed transformation via social entrepreneurship model. Academy of Entrepreneurship Journal, 25(1), 1-7.

Ariyadi, A. (2018). Bisnis Dalam Islam. Jurnal Hadratul Madaniyah, 5(1), 13-26.

Ashraf, M. A. (2019). Theory of Islamic entrepreneurship: a conceptual paper. International Journal of Entrepreneurship, 23(3), 1-12.

Azha, L., Baharuddin, S., Salahuddin, S. S., \& Afandi, M. R. (2013). The practice and management of Waqf education in Malaysia. Procedia-Social and Behavioral Sciences, 90, 22-30.

Bani, H., Jaaffar, M. Y., \& Katan, M. (2017). An overview of governance and accountability of tahfiz institutions in Malaysian: Religious Councils Perspective. In SHS Web of Conferences (Vol. 36, p. 00028). EDP Sciences.

Bakar, M. F. A., \& anak Jimel, C. (2020). Attitude towards Sustainable Product among Malaysian Consumers. Environment-Behaviour Proceedings Journal, 5(SI3), 3-9.

Darusalam, G., \& Hussin, S. (2016). Metodologi penyelidikan dalam pendidikan: Amalan dan analisis kajian. Penerbit Universiti Malaya.

Fatah, M. A. (2014). Applying stakeholder approach in developing accountability indicators for tahfiz centers.

Harizan, S. H. M., \& Mustafa, M. S. (2020). Islamic Entrepreneurship: Analysis of Research Trend. Islāmiyyāt, 42(2), 71-84.

Ismail, S. (2016). Institusi Tahfiz di Malaysia: Prospek dan Cabaran. Simposium Antarabangsa Tahfiz Sempena Sambutan, 50.

Kamal, A., \& Seman, A. C. (2017). Pembiayaan Wakaf di Majlis Agama Islam Negeri Terpilih: Potensi Pelaksanaan di Peringkat Institusi Pengajian Tinggi. TAFHIM: IKIM Journal of Islam and the Contemporary World, 10.

Kamaruddin, N., \& Wahid, H. (2020). Potensi dan Cabaran Pengusaha Perusahaan Kecil dan Sederhana (PKS) dalam Pemasaran Produk Makanan Halal semasa Pandemik Covid-19. Journal of Management and Muamalah, 10(2), 1-20.

Litvaj, I., \& Poniščiaková, O. (2014). Entrepreneurship and quality management. Entrepreneurship and Sustainability Issues, 1(4), 204.

Mardia, M., Hasibuan, A., Simarmata, J., Lifchatullaillah, E., Saragih, L., Purba, D. S., ... \& Tanjung, R. (2021). Kewirausahaan. Yayasan Kita Menulis. 
Mebroui, T., \& Mosbah, A. (2020). Islamic entrepreneurship: Issues and debates. International Journal of Management and Commerce Innovations, 7(2), 461-468.

Nawi, N. H. M., \& Salleh, N. H. (2017). Pembinaan model pengajian tahfiz di Malaysia. O-JIE: Online Journal of Islamic Education, 5(1), 1-11.

Nawi, N. H. M., Yusuff, N. A., Yaacob, M. B. C., \& Salleh, N. H. (2014). Matlamat dan halatuju sistem pengajian tahfiz di Kelantan: satu pengamatan awal.

Noor, H. M., Imang, U., Ramli, A. M., Rahman, R. A., \& Afrizal, T. (2021). New Norm for Traditional Food Business by SMEs Entrepreneurs: Case Study in Kota Kinabalu, Sabah. Environment-Behaviour Proceedings Journal, 6(16), 13-19.

Othman, A. M. A., \& Anas, N. (2020). Evolusi Tadbir Urus Tahfiz Swasta di Malaysia. Jurnal Islam dan Masyarakat Kontemporari, 21(2), $127-133$.

Ramadani, V. (2021). Islamic entrepreneurship. In World Encyclopedia of Entrepreneurship. Edward Elgar Publishing.

Ridza, B. H., Jalil, R. A., Sipan, I., \& Nukman, Y. (2017, November). Critical success factor (CSF) service delivery for tahfiz institution teaching \& learning environment. In AIP Conference Proceedings (Vol. 1903, No. 1, p. 040003). AIP Publishing LLC.

Sahut, J. M., \& Braune, E. (2021). Financial issues of entrepreneurship. In World Encyclopedia of Entrepreneurship. Edward Elgar Publishing

Syahrul, S., \& Abdullah, M. W. (2019). Islamic Entrepreneurship Based on The Concept of Honesty. Jurnal lqtisaduna, 1(1), 39-50.

Zéman, Z., \& Bogdan, A. (2019). Marketing strategy and building brand value on the Hungarian market. Ekonomicko-manazerske spektrum, 13(2), 1-9. 